\title{
PSP and NT-proCNP assessed for predisposition to infection
}

\author{
Frederic Lajaunias
}

See related research by Gouel-Chéron et al., http://ccforum.com/content/17/3/434

Gouel-Chéron and colleagues have recently published a pilot study [1] on which we would like to offer the following comments.

As the paper currently appears, it is unclear whether in fact the study aimed at evaluating the predictive value of pancreatic stone protein/regenerating protein (PSP) and amino-terminal pro-C-type natriuretic peptide (NTproCNP) for a predisposition to infection in non-infected systemic inflammatory response syndrome (SIRS) trauma patients under mechanical ventilation, or whether it rather aimed at evaluating the predictive value (that is, prognosis) of the biomarkers for sepsis development. Indeed, the authors omitted to mention that the assessment was carried out in patients exclusively before the occurrence of a hospital-acquired infection. This certainly explains why there are only 16 patients plotted in Figure 1 and not 21 (36\% of 61 patients) as one would have otherwise expected. A non-equivocal use of 'prediction' is therefore essential.

Providing these indications would have allowed to put the results into perspective with recent studies published in Critical Care on PSP ability to differentiate patients with sepsis from those with a non-infective SIRS [2] or on NT-proCNP ability to confirm sepsis and correlate with markers of bacterial infection [3].

Instead of analyzing the role of PSP and NT-proCNP in the prediction of sepsis, the authors seem to have actually predicted future hospital-acquired infection in the intensive care unit. Stating that the study assesses the prediction of sepsis is therefore clearly a misleading shortcut, since in fact the occurrence of infection, sometime later than the time-point of analysis of the biomarkers, will classify these SIRS patients as septic by definition.

\begin{abstract}
Abbreviations
NT-proCNP: Amino-terminal pro-C-type natriuretic peptide; PSP: Pancreatic stone protein/regenerating protein; SIRS: Systemic inflammatory response
\end{abstract} syndrome.

\section{Competing interests}

$\mathrm{FL}$ is a shareholder of Lascco SA, Geneva, Switzerland, which has rights to license PSP worldwide.

Received: 14 July 2013 Accepted: 23 August 2013

Published: 05 Sep 2013

\section{References}

1. Gouel-Chéron A, Dupin M, Chanteperdix M, Chaillol I, Venet F, Pachot A, Monneret G, Floccard B, Allaouchiche B: Concomitant assessment of PSP and NT-proCNP as predictive markers of sepsis in severe trauma patients under mechanical ventilation. Crit Care 2013, 17:434.

2. Llewelyn MJ, Berger M, Gregory M, Ramaiah R, Taylor AL, Curdt I, Lajaunias F, Graf R, Blincko SJ, Drage S, Cohen J: Sepsis biomarkers in unselected patients on admission to intensive or high-dependency care. Crit Care 2013, 17:R60.

3. Koch A, Voigt S, Sanson E, Dückers H, Horn A, Zimmermann HW, Trautwein $C$, Tacke F: Prognostic value of circulating amino-terminal pro-C-type natriuretic peptide in critically ill patients. Crit Care 2013, 15:R45.

\section{$10.1186 / \mathrm{cc} 12883$}

Cite this article as: Lajaunias: PSP and NT-proCNP assessed for predisposition to infection. Critical Care 2013, 17:450
Correspondence: frederic.lajaunias@lascco.com

Lascco SA, 1211, Geneva 3, Switzerland

\section{Submit your next manuscript to BioMed Central and take full advantage of:}

- Convenient online submission

- Thorough peer review

- No space constraints or color figure charges

- Immediate publication on acceptance

- Inclusion in PubMed, CAS, Scopus and Google Scholar

- Research which is freely available for redistribution

Submit your manuscript at www.biomedcentral.com/submit

C) BioMed Central 